\title{
MENYEMPURNAKAN SIARAN TELEVISI MOBIL DENGAN INOVASI ANTENA
}

\author{
Roni Kartika Pramuyanti \\ Fakultas Teknik, Program Studi Teknik Elektro \\ Universitas Semarang \\ Email: ronikartika@ymail.com
}

\begin{abstract}
ABSTRAK
Memperhatikan beberapa parameter yang ada akan membuat kesempurnaan siaran televisi mobil. Salah satu dari hal itu adalah dengan pengaturan keberadaan antena dari televisi mobil dan beberapa komponen lain yang diperlukan. Dari komponen-komponen penunjang ada beberapa parameter yang berpengaruh pada tampilan dari monitor televise mobil untuk kita lihat. Untuk dapat menerima siaran televisi secara optimal, bersama antenna terdapat rangkaian booster yang fungsinya sama dengan amplifier untuk menguatkan sinyal atau secara perhitungan akan menguatkan tegangan dari tegangan masukan antenna 12 Volt. Dari parameter yang ada, besar frekuensi sangat berpengaruh pada baik buruknya penerimaan siaran televisi mobil. Daya pancar dan terima antena berbanding terbalik dengan panjang atau jarak. Dengan menggunakan antenna serta booster DXXN1508 penguatan booster adalah 40-46 kali. Jika secara perhitungan diambil penguatan $45 \mathrm{x}$, maka dengan tegangan masukan antenna 12 $\mathrm{V}$, maka akan didapat tegangan keluaran yang sangat besar.
\end{abstract}

Kata kunci: antena, booster DXXN 1508, monitor televisi, amplifier, daya pancar dan daya terima.

\section{ABSTRACT}

The perfect mobile television's can get with some ways which one of these is control the antenna's mobile's television. Without the antenna, thereis some athers component. From these interface component, there are some parameters which can the televition's broadcast is very good, with antenna there is booster circuit and the function of this is same as the amplifier to stronger the televition's signal. In this research can be stronger the voltage from $12 \mathrm{~V}$. The other important parameter is frequency. Transmit power and receive power are inversely proportional to the wavelength or or distance. If we are use antenna and DXXN1508 booster the stronger of signal is 40-46. If we take 45 value, so 12 volt input's voltage can give output's voltage of great value.

Keywords: antenna, DXXN 1508 booster, televition's monitor, transmit power and receive power.

\section{PENDAHULUAN}

Televisi mobil mempunyai spesifikasi khusus sehingga dapat digunakan dalam kondisi bergerak atau move. Seperti halnya pada siaran radio yang digunakan pada kondisi bergerak pasti akan mempunyai banyak gangguan apalagi jika mengingat bahwa televisi mobil membawa sinyal video atau gambar tidak hanya siaran audio atau suara. Oleh karena itu dibutuhkan pilihan antara televisi analog atau digital, penggunaan booster serta antena.

Permasalah yang didapatkan dengan penggunaan Televisi mobil dalam kondisi bergerak cenderung tidak bersih atau banyak mengalami gangguan. Dari hal tersebut perumusan masalah dari penelitian ini adalah berusaha mendapatkan penerimaan video atau gambar serta suara pada pesawat televisi yang bersih dan jernih secara optimal.

Dari sedikit permasalahan yang timbul diatas, peneliti berusaha memasang antena pada mobil dimana dapat menangkap siaran televisi cecara UHF (Ultra High Frekuency, frekuensi yang sangat tinggi). Selain itu peneliti juga mengatur kedudukan antena yang biasanya berada diluar tetapi menempel body mobil.

Tujuan umum dari penelitian ini adalah dapat memperoleh atau menangkap siaran televisi yang paling baik pada perjalanan menggunakan mobil. Adapun tujuan khusus dari penelitian ini adalah sama dengan tujuan umumnya namun hal ini terjadi pada mobil Ertiga. 


\section{METODOLOGI PENELITIAN}

Untuk mencapai tujuan tersebut digunakan metodologi aplikasi langsung baik pemilihan dan pemasangan antena mobil serta melakukan perjalanan dari yogya ke solo maupun semarang. Bahan dan materi Penelitian meliputi bahan penelitian yang dipergunakan adalah: a). Antena mobil UHF, b). TV mobil 7 inchi Avelino.

Adapun materi yang dipergunakan dipergunakan pada penelitian antara lain : a). Menampilkan acara TV yang berasal dari VCD dan DVD, b). Menampilkan acara TV yang berasal dari stasiun TV yang ada c). Menganalisa siaran masing-masing stasiun TV.

Selain bahan serta materi yang digunakan atau diteliti, akan dilakukan pula perancangan penelitian, yaitu menganalisa tampilan gambar maupun suara masing-masing siaran stasiun TV pada monitor TV mobil, menyesuaikan letak serta kedudukan antenna sehingga didapatkan tampilan yang sempurna.

\subsection{Perjalanan Langsung ke Solo}

Melakukan perjalanan darat menggunakan mobil pribadi dari Yogyakarta menuju Solo atau Surakarta tidak banyak menghadapi tantangan dalam perolehan sinyal untuk melakukan hubungan lewat handphone ataupun menikmati siaran televisi lokal di dalam mobil. Namun begitu, untuk beberapa daerah Klaten tidak banyak atau sedikit sekali BTS yang ada disana, bahkan sebagai daerah yang terkenal dengan blank spot sinyal dari satelit atau televisi banyak yang tidak bisa diterima dengan baik.

\subsection{Perjalanan Langsung ke Semarang}

Perjalanan ke Semarang dari Yogyakarta menghadapi banyak tantangan terutama dengan medan yang dilalui menggunakan mobil. Lembah, bukit bahkan gunung akan dilalui. Dengan menghadapi medan seperti itu, maka medan elektromagnet tidak akan bisa menembus atau secara otomatis siaran televisi, radio maupun sinyal komunikasi Handphone pun akan banyak terkendala atau tidak bisa tertangkap sama sekali. Bahan penelitian yang digunakan antara lain:

\subsubsection{Antena}

Antena merupakan komponen elektronika yang biasa digunakan dalam telekomunikasi. Digunakannya antena adalah karena antena sangat berguna antuk pemancaran maupun penerimaan siaran baik audio maupun video. Antena adalah transformator/struktur transmisi antara gelombang terbimbing (saluran transmisi) dengan gelombang ruang bebas atau sebaliknya. Antena adalah salah satu elemen penting yang harus ada pada sebuah teleskop radio, TV, radar, dan semua alat komunikasi nirkabel lainnya. Sebuah antenna adalah bagian vital dari suatu pemancar atau penerima yang berfungsi untuk menyalurkan sinyal radio ke udara

Fungsi antena adalah untuk mengubah sinyal listrik menjadi sinyal elektromagnetik, lalu meradiasikannya ke udara/ruang bebas). Sebaliknya, antena juga berfungsi menerima sinyal elektromagnetik (penerima energi elektromagnetik dari ruang bebas) dan mengubahnya menjadi sinyal listrik. Ada antena yang melakukan kedua fungsi (peradiasi dan penerima) sekaligus.

Faktor utama yang menentukan seberapa bagusnya sebuah antena dalam menerima signal yaitu jarak dan arah antara antena itu dengan pemancar stasiun televisi (transmitter), dan juga kekuatan pemancar stasiun tersebut.

Pada sebuah radio, antena hanya menjalankan fungsi penerima saja. Televisi adalah sebuah media telekomunikasi terkenal yang digunakan untuk memancarkan dan menerima siaran gambar bergerak, baik itu yang monokrom ("hitam putih") maupun warna, biasanya dilengkapi oleh suara. "Televisi" juga dapat diartikan sebagai kotak televisi, rangkaian televisi atau pancaran televisi. Kata "televisi" merupakan gabungan dari kata tele ("jauh") dari bahasa Yunani dan visio ("penglihatan") dari bahasa Latin. Sehingga televisi dapat diartikan sebagai telekomunikasi yang dapat dilihat dari jarak jauh. Penemuan televisi disejajarkan dengan penemuan roda, karena penemuan ini mampu mengubah peradaban dunia. Di Indonesia 'televisi' secara tidak formal disebut dengan TV, tivi, teve atau tipi.(http://google.com).

Ada istilah lain mengenai antena yaitu front-to-back-ratio, artinya berapa bagus sebuah antena dapat menerima signal yang datang dari arah antena itu menghadap dibandingkan yang datang dari arah yang berlawanan.

Frekuensi yang digunakan pada televisi adalah pada pita frekuensi VHF (Very High Frequency) dan UHF (Ultra High Frequency). VHF dan UHF adalah sebuah bandwidth yang digunakan memancarkan sinyal radio dan TV pada frekuensi tinggi. Adapun batasan dari kedua band itu adalah : VHF : $30 \mathrm{MHz}-$ $300 \mathrm{MHz}$, saluran 2 - 13 pada TV, UHF: $300 \mathrm{MHz}-3 \mathrm{GHz}$, saluran 14 keatas pada TV. Megahertz 
artinya "sejuta cycles per detik," jadi "300 megahertz" artinya pemancar stasiun radio tersebut berosilasi pada frekuensi 300,000,000 cycles per detik.

\subsubsection{Televisi}

Ada 2 jenis televisi dimana kedua jenis televisi ini juga mempunyai perbedaan prinsip pada penerimaannya yaitu :1. Televisi Analog, 2. Televisi Digital atau DTV, 3. Transisi TV analog ke TV Digital. Pemicu perkembangan TV digital_antara lain : Yang pertama perubahan lingkungan eksternal :1. Pasar televisi analog yang sudah jenuh, 2._Kompetisi dengan sistem penyiaran satelit dan kabel. Sedangkan pemicu yang kedua adalah Perkembangan Teknologi yang meliputi teknologi pemrosesan sinyal digital, teknologi Transmisi digital, teknologi semikonduktor serta teknologi peralatan yang beresolusi tinggi

\subsubsection{Booster}

Booster adalah alat untuk memperkuat sinyal dari antenna TV ke sebuah atau beberapa buah TV pada bagian outputnya, sehingga kualitas gambar tidak menurun meskipun posisinya bergerak. Booster antenna TV mobil selalu serangkai dengan antenanya. Peletakan bisa secara indoor, bisa juga outdoor. Walaupun peletakan di luar mobil akan membuat booster serta antenna rawan kerusakan, namun penerimaan sinyal dari radio ataupun video akan baik. Antena maupun booster ini biasanya sudah dirangkai di dalam suatu tempat dari bahan isolator yang akan tahan dari panas maupun hujan, sehingga tidak mudah korosi serta bergeser.

Jarak dari antenna maupun booster dari televisi mobil Ertiga yang digunakan disini adalah Standing wave ratio disingkat SWR kadang-kadang disingkat dengan nama VSWR (Voltage Standing Wave Ratio). Bila impedansi saluran transmisi tidak sesuai dengan transceiver maka akan timbul daya refleksi (reflected power) pada saluran yang berinterferensi dengan daya maju (forward power). Interferensi inimenghasilkan gelombang berdiri (standing wave) yang besarnya tergantung pada besarnya daya refleksi. VSWR didefinisikan sebagai perbandingan tegangan maksimum dan tegangan minimum gelombang berdiri pada saluran transmisi.

\section{HASIL DAN PEMBAHASAN}

\subsection{Antena TV Mobil}

Antena TV mobil adalah antena TV (VHF/UHF) yang berbentuk kompak dan didesain khusus untuk pemakaian yang mobile (sering berpindah tempat), misalnya untuk pemakaian pada TV mobil atau untuk yang menggunakan TV Tuner pada notebook (laptop). Antena ini memiliki Built-in booster, sehingga gambar yang dihasilkan memiliki kualitas yang sangat baik.

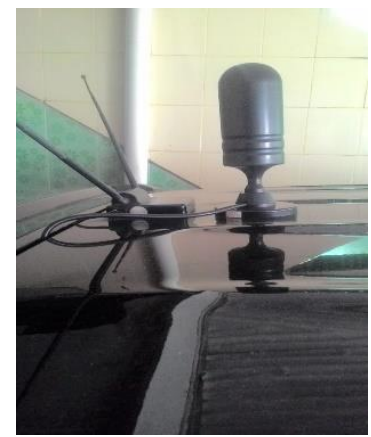

\section{Gambar 1. Antena TV Mobil Pada Penelitian}

Jika ingin memperkuat kemampuannya lagi dalam menerima sinyal frekuensi radio maupun siaran TV, terutama pada kondisi di jalur antar kota, bisa memasang sebuah antena tambahan lagi. Pasalnya versi ini sudah dibekali kemampuan untuk menangkap frekuensi UHF (Ultra High Frequency) maupun VHF (Very High Frequency).

Panjang gelombang minimal dari antenna disini ditentukan cepat rambat gelombang di udara dan frekuensi dari masing-masing televisi yang dirumuskan dengan: 
$\lambda=\frac{e}{f}$

dimana : $\lambda=$ panjang gelombang (meter);

$\mathrm{c}=$ cepat rambat gelombang di udara $(\mathrm{m} / \mathrm{s})$;

$\mathrm{f}=$ frekuensi gelombang $(\mathrm{Hz})$

Adapun hubungan gelombang dan daya terima adalah:

$\mathrm{P}=\frac{V^{2}}{R} \rightarrow \mathrm{R}=\rho \frac{\mathbb{I}}{A}$

Dimana : $\quad \mathrm{P}=$ daya terima antenna $(\mathrm{W})$;

$\mathrm{V}=$ tegangan penghantar $(\mathrm{V})$;

$\mathrm{R}=$ tahanan antenna $(\Omega) ; 1=\lambda=$ panjang gelombang $(\mathrm{m})$

Dari hubungan diatas terlihat bahwa panjang gelombang akan berbanding terbalik dengan daya terima antena.

\subsection{Booster}

Booster antena merupakan perangkap tambahan yang akan menambah kekuatan antenna dalam menerima sinyal. Penguat sinyal TV Uhf, penambah kekuatan sinyal TV digital maupun TV analog. Booster merupakan penguat atau simplifier. Penguat ini terdapat pengontrol frekuensi otomatis. Penguat ini terbuat dari transistor yang di produksi oleh pabrik jepang, Penguat di gunakan untuk menerima program televisi dari jarak jauh dengan hasil maksimal. Ketika penerimaan sinyal lemah, penguat meminimalkan bintik-bintik dan warna televisi lebih kontras.

Alat ini berkekuatan $(\mathrm{A}) \pm 40-46$ desibel, Untuk mencari tegangan keluaran dari booster ini dapat diambil persamaan penguatan atau gain :

$$
\begin{aligned}
\mathrm{A}=20 . \log & \frac{V_{0}}{V_{i}} \\
\text { dimana : } & \mathrm{A}: \text { kekuatan alat/ booster } \\
& \mathrm{V}_{\mathrm{o}} \text { : tegangan keluaran }(\mathrm{V}) \\
& \mathrm{V}_{\mathrm{i}} \text { : tegangan masukan ke alat }(\mathrm{V})
\end{aligned}
$$

Untuk hasil penggunaan penguat yang maksimal, jalur kabel coaxial 75 ohm yang di pakai sesuai dengan penguat. Penguat atau Booster terbaik sekalipun tidak akan berfungsi dengan baik jika kualiatas kabel yang di pakai tidak bagus.

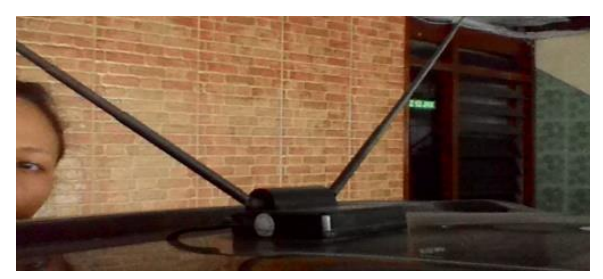

Gambar 2. Booster Pada Antenna TV Mobil

\subsection{Pembahasan}

Ada beberapa parameter yang perlu diperhitungkan pada penerimaan siaran video di dalam mobil Ertiga, baik pada penangkapan siaran televisi maupun VCD/ DVD. Pada siaran TV lokal maupun nasional perlu diketahui frekuensi masing-masing TV yang dimaksud. Pembagian frekuensi dari TV swasta maupun TVRI antara lain : Frekuensi dari masing-masing Televisi telah diketahui, semuanya mempunyai harga dalam batas kawasan Ultra High Frekuency $(300 \mathrm{Mhz}-3 \mathrm{GHz})$. Nilai kecepatan cepat rambat gelombang di udara adalah $3 \times 10^{8} \mathrm{~m} /$ detik, dengan demikian antenna yang digunakan juga harus mempunyai panjang gelombang minimal berdasarkan persamaan 2.1 adalah sebagai berikut : 
Tabel 1. Daftar frekuensi dan panjang gelombang televisi

\begin{tabular}{clc}
\hline Nama Televisi & Frekuensi $(f)$ & Panjang Gelombang $(\lambda$, \\
\hline TVRI & $: 615,31 \mathrm{MHz}$ & $0,488 \mathrm{~m}$ \\
TRANS TV & $: 535,31 \mathrm{MHz}$ & $0,560 \mathrm{~m}$ \\
MNC TV & $: 599,25 \mathrm{MHz}$ & $0,501 \mathrm{~m}$ \\
INDOSIAR & $: 631,3 \mathrm{MHz}$ & $0,475 \mathrm{~m}$ \\
ANTV & $: 679,25 \mathrm{MHz}$ & $0,442 \mathrm{~m}$ \\
RCTI & $: 647,31 \mathrm{MHz}$ & $0,463 \mathrm{~m}$ \\
SCTV & $: 663,31 \mathrm{MHz}$ & $0,453 \mathrm{~m}$ \\
GLOBAL TV & $: 711,31 \mathrm{MHz}$ & $0,422 \mathrm{~m}$ \\
TV ONE & $: 727,31 \mathrm{MHz}$ & $0,412 \mathrm{~m}$ \\
KOMPAS TV & $: 527,31 \mathrm{MHz}$ & $0,569 \mathrm{~m}$ \\
METRO TV & $: 759,31 \mathrm{MHz}$ & $0,395 \mathrm{~m}$ \\
TRANS 7 & $: 695,25 \mathrm{MHz}$ & $0,431 \mathrm{~m}$ \\
\hline
\end{tabular}

Dari tabel dan hasil perhitungan diatas terlihat bahwa Metro TV mempunyai panjang gelombang minimal paling pendek, sedangkan frekuensinya terbesar sehingga penerimaan yang dapat disaksikan pada TV mobilnya ternyata adalah yang paling baik.

Antena serta booster yang digunakan disini adalah DXX N1508. Dari antenna dan booster yang digunakan dapat diketahui besar bahwa tegangan keluaran antenna dari rumus 2.3. Yaitu:

$\mathrm{A}=20 . \log \frac{V_{0}}{V_{\tilde{i}}} \rightarrow$ Jika diambil kekuatan antenna $45 \mathrm{x}$,

Dengan tegangan masukan $12 \mathrm{~V}$

Maka: $45=20 . \log \frac{V_{0}}{V_{i}} ; \log \frac{V_{0}}{V_{i}}=2,25 \rightarrow \frac{V_{0}}{V_{i}}=10^{2,25}=181,9701$, sehingga $V_{o}=2183,641 \mathrm{~V}$

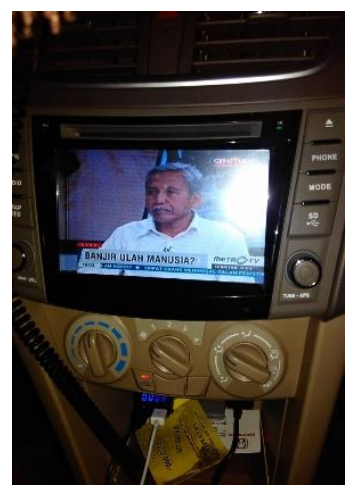

\section{Gambar 3. Hasil Siaran Metro TV Dalam TV Mobil Ertiga}

\section{KESIMPULAN}

Dari penelitian yang dilakukan dapat disimpulkan:

1) Penerimaan siaran televisi mobil akan jernih, bersih jika komponen yang digunakan cocok atau sesuai dengan petunjuk dari buku petunjuknya.

2) Panjang gelombang yang terhitung adalah yang terpendek tetapi dengan frekuensi terbesar yaitu siaran dari televisi metro dengan frekuensi 759,31 MHz dan panjang gelombang 0,395 meter.

3) Dari penelitian ini besar penguatan sesuai buku petunjuk adalah $40-46 \mathrm{~dB}$. Jika diambil penguatan 45, makabesar tegangan keluaran dari antenna adalah 2183,641 Volt.

\section{ACUAN REFERENSI}

Analisa antenna untuk optimalisasi siaran TV mobil, Roni Kartika Pramuyanti. 


\section{DAFTAR PUSTAKA}

[1] Eko Riyanto SUTOMO, 2012, Menyongsong Penggunaan Penyiaran TV Digital di Indonesia, Buletin Informasi SDPPI Edisi ketiga.

[2] Cyclades (Syros), 2008, FirstBroadcasts 60 UHF.

[3] Tjahyono Bambang Heru, 2006, Sistem Jaringan Penyiaran Radio \& TV Dimasa Mendatang.

[4] www. Google.search. DTT around the world and digital television transition. Unduh 10 Agustus 2015 